\title{
The Effect of IFRS Convergence on Ownership of Foreign Investors in Indonesia
}

\author{
Anesella Shara ${ }^{1}$, Aria Farah Mita ${ }^{*}$ \\ ${ }^{1}$ Faculty of Economics and Business, Universitas Indonesia, Depok 16424, Indonesia \\ *aria.farahmita@gmail.com
}

\begin{abstract}
This research aims to provide empirical evidence on the effect of the convergence of IFRS on foreign ownership in Indonesia. Tests are carried out using models from Hamberg et al. (2013). The results of this study show that the convergence of IFRS increases the number and percentage of foreign ownership by the countries adopting IFRS in small enterprises in Indonesia. This proves that the convergence of IFRS has a positive impact on the world of investing in Indonesia, especially for investors from countries adopting IFRS and for small-scale public companies.
\end{abstract}

Keywords: IFRS Convergence, Number and Percentage of Foreign Ownership.

\section{INTRODUCTION}

The Financial Accounting Standard is the pillar of a country's capital market ${ }^{1}$. have stated that the financial statement is the primary information source influencing investors' decision making. An information constraint is one of the key issues facing foreign investors who are investing outside of their home countries. Distances, differences in economic conditions, and cultural differences limit the investor's ability to reliably assess and supervise the investee in the host country ${ }^{2-4}$. In this case, the uniformity of local accounting standards with international accounting standards is considered essential to reduce information barriers between investors and investee who are in different countries ${ }^{4,5}$.

In Indonesia, the application of financial accounting standards' (PSAK) convergence of International Financial Reporting Standard (IFRS) was initiated in 2012. This convergence aims to produce financial statements that have a high level of credibility and are attractive to foreign investment. Although already in force, some observers in Indonesia still doubt the positive impact of the IFRS convergence on foreign investment.

The present study was conducted to ascertain how the convergence of IFRS in Indonesia affects the ownership of foreign investment. This study will attempt to fill a contemporary research gap by providing empirical evidence as to the effect of the convergence of IFRS on foreign ownership in Indonesia. Moreover, in contrast with previous research that often refers to a change of ownership of institutional investors ${ }^{3,6}$, this study will look at the impact of IFRS convergence on the overall types of foreign investors. In this study, foreign ownership will be considered using two proxies: the number of investors and the percentage of foreign ownership.

\section{LITERATURE REVIEW AND HYPOTHESIS \\ IFRS Convergence in Indonesia}

IFRS Convergence in Indonesia has been carried out since 2008. Stages of IFRS convergence have been conducted in several stages, including the adoption phase (2008-2010), the final preparation stage (2011), and the implementation phase $(2012)^{7}$. Indonesia has not had a 'Big Bang' IFRS adoption. Indeed, there are significant differences in time and substance to the application of IFRS in Indonesia.

The time difference in the implementation of PSAK convergence of IFRS has a lag of one year. This means GAAP effective from January 1, 2015 in Indonesia is broadly convergent with International Financial Reporting Standards (IFRS) effective from January 1, 2014. DSAK IAI has succeeded in minimizing the time differences in implementation between the two standards, from three years on January 1st 2012 for the version of IFRS as of January 1st 2009 to one year from January 1st, 2015 for the version of IFRS as of January 1st, 2014.

The Indonesian Institute of Accountants (IAI), as the Accounting Standards Board in Indonesia, mentions the various benefits that can be gained from this IFRS convergence. Some of these benefits include improving comparability, improving the quality of accounting information, and increasing the transparency of Indonesian companies' financial statements. This is expected to encourage foreign investment into Indonesia. Moreover, IFRS convergence can reduce the cost of reporting for multinational companies and the cost of financial analysis for the analyst.

The implementation of PSAK convergence of IFRS has been carried out for four years. However, many obstacles have been encountered in the adoption of IFRS in Indonesia, such as a lack of readiness of the Financial Accounting Standards Board (DSAK) as a standard setter in Indonesia, discrepancies in legislation, and a lack of 
readiness of human resources and education in Indonesia.

\section{Developing Hypothesis}

Many previous studies prove that the adoption of IFRS will increase foreign ownership. This is owing to increased comparability and quality of financial statements that subsequently reduce the cost of acquisition and processing of financial information ${ }^{4,5,8}$.

H1a: IFRS Convergence has a positive effect on the number of foreign investors in Indonesia.

H1b: IFRS Convergence has a positive effect on the percentage of foreign ownership in Indonesia.

IFRS Convergence in the investment destination country has a different effect on investors who are in different countries $^{9}$. Investors who are in the IFRS adopting country generally feel the ease of changes in accounting standards within the investee country. This ease occurs owing to the fact that the company being analyzed can be directly compared with local companies. Instead, investors from countries that do not adopt IFRS do not necessarily feel the same benefits. Thus it is suspected that improvements in the quality and comparability of financial statements after the adoption of IFRS in one country can be better perceived by investors from countries where IFRS occurs. The second hypothesis in this study is therefore stated as:

H2a: The effect of IFRS convergence in increasing the number of foreign investors coming from IFRS adopting countries is higher than its effect on the number of investors from the non-adopters.

H2b: The effect of IFRS convergence in increasing the percentage of ownership by foreign investors who come from IFRS adopting countries is higher than the effect on the percentage of ownership of the non-adopters.

Based on the second hypothesis, the research will also divide the sample companies into two groups based on their size, with sample groups of both large and small-scale companies. This approach is based on that employed by previous studies ${ }^{4,5,10}$ which have illustrated that increased comparability has a different effect on the proportion of foreign investment in each company. Foreign investors in the form of institutions often seek investment opportunities in large and prominent companies, because the risk of the investment is relatively small when compared to investing in small companies ${ }^{2}$.

However, subsequent studies by Hamberg ${ }^{9}$ have shown different results. Research results indicate that the effect of the adoption of IFRS on the percentage of ownership by foreign investors from adopting countries has a greater impact for small-scale issuers. In a study conducted by Hamberg ${ }^{9}$, the scale of the company is divided by the median market capitalization. Companies that have a market capitalization above the median are classified as large companies, small companies otherwise. The effect of IFRS adoption is more significant in increasing foreign ownership in small companies because the impact of adopting IFRS in improving the quality and comparability of small companies' financial statements is higher than its impact on large scale issuers, who already have a good quality of financial reporting.

H3a: The increase in the number of foreign investors from adopting countries is more significant for smaller companies than large companies.

H3b: The increase in the percentage of foreign ownership from adopting countries is more significant for smaller companies than large companies.

\section{RESEARCH METHOD}

The research presented here is part of a study conducted to determine the effect of IFRS convergence on foreign ownership in Indonesia. The study sample includes non-financial companies listed on the Indonesia Stock Exchange. Financial companies are excluded in this study because they have a different business nature to other industries. The observation period was undertaken from 2008 to 2014. The selection of this time frame is owing to the convergence of IFRS in Indonesia coming into effect for all public companies in January 2012. The study was conducted using data from four years before the adoption of IFRS (2008-2011) and three years after the adoption of IFRS (2012-2014). The range of time taken gave fairly representative changes in the number and percentage of ownership as a result of the convergence of IFRS in Indonesia. The number of samples in this study amounted to 1463.

This research uses secondary data from financial reports and investor share ownership data from Thomson Financial Ownership of Service. To test the hypothesis, the study uses a model developed by Hamberg ${ }^{9}$. The model used in this study is as follows:

$$
\begin{aligned}
y_{i t}= & \beta_{0}+\beta_{1} \text { GNRL_TREND }_{t}+\beta_{2} \text { IFRS_TREND } D_{t}+\beta_{3} \text { ROA }_{i t} \\
& +\beta_{4} F L E V_{i t}+\beta_{5} \text { MCAP_LN }_{i t}+\beta_{6} M_{-} B_{i t}+\beta_{7} L I Q_{i t}+\beta_{8} O W N_{i t} \\
& +\beta_{9} \text { COM }_{i t}+\epsilon_{i t}
\end{aligned}
$$


The dependent variable (Yt) in this study is the number of investors and the percentage of foreign ownership in Indonesia. The number of foreign investors is measured by dividing the number of foreign owners by the total number of owners in the company at the end of the period. The percentage of foreign ownership is measured by dividing the percentage of capital ownership by foreign investors with total capital holdings at the end of the period. Sources of data are retrieved from the Thomson Financial Ownership (TFO) database. Hypothesis 2 variables on foreign ownership will be retrospectively split into two groups: the foreign ownership of foreign origin adopters and non-adopters of IFRS. This is obtained from the investor's home country data in TFO. In the context of this study, 'foreign investors' means investors from different countries to the company's home country. Investors from the state Tax Haven are excluded.

The independent variables in this study use a "TREND model". Trend models are used to indicate the presence of progressive changes in these variables. Two trends were used in this study: GNRL_TREND and IFRS_TREND. GNRL_TREND comprises a yearly increase in the national economy's performance, from 2008 to 2014. This variable is used to control for the effects of macroeconomic performance on the dependent variable. The IFRS_TREND coefficient will show the effect of the convergence of IFRS on the number of investors and the percentage of foreign ownership from 2008 to 2014. IFRS_TREND variables in this study will show a yearly increase which describes the IFRS convergence process in Indonesia.

This study using the Tobit estimation model. The latter is used to estimate whether the value of the dependent variable is limited to a certain range. In this study, the dependent variable used is the value of the proportion of the number of investors and the percentage of foreign ownership in Indonesia. The value of the dependent variable in the range is thus 0 to 1 . The Tobit model with a lower limit of 0 and an upper limit of 1 is therefore considered appropriate to estimate the model in this study.

\section{RESULT AND DISCUSSION}

The first hypothesis testing is presented in Table 1, in columns (1a) and (1b). In the table it appears that the variable GNRL_TREND and IFRS_TREND, both in the ownership model (0.630 and 0.336) and the model number of investors (0.318 and 0.864), were not significant. Alongside this, it is demonstrated that GNRL_TREND and IFRS_TREND do not significantly affect FOREIGN_NO and FOREIGN_OWN. With these results, the first hypothesis developed at the beginning of the study was rejected. There is no significant effect of IFRS convergence on the number and percentage of foreign ownership in Indonesia.

Based on the test results of the model (2a) to (2d), it can be concluded that the convergence of IFRS does not have a significant effect in increasing the number of foreign investors and the percentage of foreign ownership from both adopting and non-adopting countries. Thus Hypothesis 2 is rejected.

Table 2 shows the results of the regression model for the third hypothesis. Testing is subdivided by splitting the sample into two groups, i.e. a sample that has a median size of companies (market capitalization) above (large) and below (small) the median value. For the overall testing performed on a large-scale company, it can be concluded that IFRS_TREND does not affect the number and percentage of foreign ownership of both types of investor in Indonesia.

In tests performed for small-scale enterprises, the results are different. In model (3h), IFRS_TREND and GNRL_TREND have respective coefficients of -0.06048 and 0.1072487 with a p-value of 0.024 and 0.014 . Both are significant at the 5\% level. Thus, the third hypothesis can be accepted. In small companies, the convergence of IFRS has a significant effect on the number of foreign investors and the percentage of ownership from IFRSadopting countries. This suggests that the convergence of IFRS has a positive effect, although the effect is still limited. These results are consistent with previous studies conducted by Hamberg ${ }^{9}$ in Sweden, which finds that the adoption of IFRS in Sweden increased foreign investment of IFRS adopting countries in small companies.

\section{CONCLUSION}

The results show that IFRS Convergence increases the number of foreign investors and the foreign ownership percentage from IFRS adopting countries in small companies. The IFRS Convergence affects the investors who come from IFRS adopting countries owing to the increased comparability felt most by this type of investor. Those who are familiar with the principles of IFRS are certainly better off with the convergence of IFRS in Indonesia. Investors can more quickly understand companies' financial statements and the accounting information processing costs for investment in Indonesia are lower. 
Table.1. Regression Result (H1 and H2)

\begin{tabular}{|c|c|c|c|c|c|c|}
\hline & \multicolumn{3}{|c|}{ Foreign Owners } & \multicolumn{3}{|c|}{ Foreign Ownership } \\
\hline & Total (1a) & IFRS (2a) & $\begin{array}{c}\text { NonIFRS } \\
(2 \mathrm{~b})\end{array}$ & Total (1b) & IFRS (2c) & $\begin{array}{c}\text { NonIFRS } \\
(2 \mathrm{~d})\end{array}$ \\
\hline $\begin{array}{l}\text { GNRL }_{-} \\
\text {TREND }\end{array}$ & $\begin{array}{l}-0,0113 \\
(0,318)\end{array}$ & $\begin{array}{l}-0,0245^{* *} \\
(0,048)\end{array}$ & $\begin{array}{l}0,0109 \\
(0,144)\end{array}$ & $\begin{array}{l}-0,0075 \\
(0,630)\end{array}$ & $\begin{array}{l}-0,0184 \\
(0,254)\end{array}$ & $\begin{array}{l}0,0104 \\
(0,176)\end{array}$ \\
\hline $\begin{array}{l}\text { IFRS } \\
\text { TREND }\end{array}$ & $\begin{array}{l}-0,0033 \\
(0,864)\end{array}$ & $\begin{array}{l}0,0204 \\
(0,172)\end{array}$ & $\begin{array}{l}- \\
0,0299 * * * \\
(0,097)\end{array}$ & $\begin{array}{l}0,0116 \\
(0,336)\end{array}$ & $\begin{array}{l}0,0297 \\
(0,148)\end{array}$ & $\begin{array}{l}-0,0225 \\
(0,245)\end{array}$ \\
\hline ROA & $\begin{array}{l}0,4672 * * * \\
(0,008)\end{array}$ & $\begin{array}{l}0,4973 * * * \\
(0,008)\end{array}$ & $\begin{array}{l}0,0085 \\
(0,956)\end{array}$ & $\begin{array}{l}0,4202 * * \\
(0,051)\end{array}$ & $\begin{array}{l}0,4978 * * \\
(0,027)\end{array}$ & $\begin{array}{l}-0,0097 \\
(0,958)\end{array}$ \\
\hline MCAP_LN & $\begin{array}{l}0,1252^{* * *} \\
(0,000)\end{array}$ & $\begin{array}{l}0,0671^{* * *} \\
(0,000)\end{array}$ & $\begin{array}{l}0,1255^{* * *} \\
(0,000)\end{array}$ & $\begin{array}{l}0,0691 \text { *** } \\
(0,000)\end{array}$ & $\begin{array}{l}0,0576^{* * *} \\
(0,000)\end{array}$ & $\begin{array}{l}0,0700 \text { *** } \\
(0,000)\end{array}$ \\
\hline FLEV & $\begin{array}{l}0,0206 \\
(0,239)\end{array}$ & $\begin{array}{l}-0,0303 \\
(0,114)\end{array}$ & $\begin{array}{l}0,0692 * * * \\
(0,000)\end{array}$ & $\begin{array}{l}0,0408 * * \\
(0,033)\end{array}$ & $\begin{array}{l}-0,0129 \\
(0,574)\end{array}$ & $\begin{array}{l}0,0732 * * * \\
(0,000)\end{array}$ \\
\hline M_B & $\begin{array}{l}-0,003^{* * *} \\
(0,000)\end{array}$ & $\begin{array}{l}-0,0014 \\
(0,441)\end{array}$ & $\begin{array}{l}- \\
0,0514^{* * *} \\
(0,000)\end{array}$ & $\begin{array}{l}-0,0319 * * \\
(0,013)\end{array}$ & $\begin{array}{l}-0,0087 \\
(0,497)\end{array}$ & $\begin{array}{l}- \\
0,0384 * * * \\
(0,000)\end{array}$ \\
\hline LIQ & $\begin{array}{l}-0,0034 \\
(0,395)\end{array}$ & $\begin{array}{l}-0,0026 \\
(0,526)\end{array}$ & $\begin{array}{l}-0,0061 \\
(0,113)\end{array}$ & $\begin{array}{l}0,0133^{* * *} \\
(0,005)\end{array}$ & $\begin{array}{l}0,0082 * \\
(0,061)\end{array}$ & $\begin{array}{l}-0,0006 \\
(0,872)\end{array}$ \\
\hline $\mathrm{COM}$ & $\begin{array}{l}0,0106^{* * *} \\
(0,002)\end{array}$ & $\begin{array}{l}0,0119 * * * \\
(0,001)\end{array}$ & $\begin{array}{l}0,0010 \\
(0,378)\end{array}$ & $\begin{array}{l}0,0044 \\
(0,184)\end{array}$ & $\begin{array}{l}0,0098^{* *} \\
(0,028)\end{array}$ & $\begin{array}{l}-0,0019 \\
(0,573)\end{array}$ \\
\hline CTRL & $\begin{array}{l}-2,002^{* * *} \\
(0,000)\end{array}$ & $\begin{array}{l}-0,0447 \\
(0,181)\end{array}$ & $\begin{array}{l}- \\
0,0818 * * * \\
(0,010)\end{array}$ & $\begin{array}{l}- \\
0,1596 * * * \\
(0,000)\end{array}$ & $\begin{array}{l}-0,0614 \\
(0,139)\end{array}$ & $\begin{array}{l}- \\
0,1417 * * * \\
(0,000)\end{array}$ \\
\hline $\mathrm{C}$ & $\begin{array}{l}-2.0024 \\
(0,000)\end{array}$ & $\begin{array}{l}-1,1062 \\
(0,000)\end{array}$ & $\begin{array}{l}-2,3806 \\
(0,000)\end{array}$ & $\begin{array}{l}-1,0812 \\
(0,000)\end{array}$ & $\begin{array}{l}-1,0819 \\
(0,000)\end{array}$ & $\begin{array}{l}-1,3339 \\
(0,000)\end{array}$ \\
\hline $\mathrm{N}$ & 1463 & 1463 & 1463 & 1463 & 1463 & 1463 \\
\hline $\mathrm{R} 2$ & 0,2261 & 0,1096 & 0,3077 & 0,0389 & 0,0400 & 0,1208 \\
\hline $\begin{array}{l}\text { Prob>F- } \\
\text { stat } \\
\text { Wald Test }\end{array}$ & $\begin{array}{r}0,000 \\
0,3967\end{array}$ & $\begin{array}{r}0,000 \\
0,0862\end{array}$ & $\begin{array}{r}0,000 \\
0.9312\end{array}$ & $\begin{array}{r}0,000 \\
0,3234\end{array}$ & $\begin{array}{r}0,000 \\
0,1328\end{array}$ & $\begin{array}{r}0,000 \\
0,8671\end{array}$ \\
\hline
\end{tabular}

Changes in foreign investment after the IFRS convergence are felt more in small companies, perhaps owing to increases in the quality and comparability of financial statements that reduce the risks attached to investing in these companies. This encourages foreign investors, especially those from IFRS adopting countries, to look for investment opportunities in small companies.

This study thus proves that the convergence of IFRS is the right policy for Indonesia. The benefits of IFRS convergence in the investment world are estimated by the Financial Accounting Standards Board as including the increased quality and comparability of financial statements, as well as increased foreign investment Indonesia, although its influence is still currently small. 
Table.2. Regression Result (H3)

\begin{tabular}{|c|c|c|c|c|c|c|}
\hline \multicolumn{7}{|c|}{ LARGE FIRM } \\
\hline & \multicolumn{3}{|c|}{ Foreign Owners } & \multicolumn{3}{|c|}{ Foreign Ownership } \\
\hline & Total (3a) & IFRS (3b) & NonIFRS (3c) & Total (3d) & IFRS (3e) & $\begin{array}{l}\text { NonIFRS } \\
\text { (3f) }\end{array}$ \\
\hline GNRL_TREND & $\begin{array}{l}0,0256 * * \\
(0,039)\end{array}$ & $\begin{array}{l}0,0004 \\
(0,486)\end{array}$ & $\begin{array}{l}0,0317 * * * \\
(0,001)\end{array}$ & $\begin{array}{l}0,0223 \\
(0,139)\end{array}$ & $\begin{array}{l}0,0247^{*} \\
(0,094)\end{array}$ & $\begin{array}{l}0,0070 \\
(0,255)\end{array}$ \\
\hline IFRS_TREND & $\begin{array}{l}-0,0887^{* * *} \\
(0,000)\end{array}$ & $\begin{array}{l}-0,0404 * * \\
(0,049)\end{array}$ & $\begin{array}{l}-0,0681 * * * \\
(0,000)\end{array}$ & $\begin{array}{l}-0,0632^{*} \\
(0,071)\end{array}$ & $\begin{array}{l}-0,0539 \\
(0,102)\end{array}$ & $\begin{array}{l}-0,0303^{*} \\
(0,085)\end{array}$ \\
\hline $\mathrm{C}$ & $\begin{array}{l}-0,8209^{* * *} \\
(0,000)\end{array}$ & $\begin{array}{l}-0,4481^{* * *} \\
(0,000)\end{array}$ & $\begin{array}{l}-0,8454^{* * *} \\
(0,000)\end{array}$ & $\begin{array}{l}-0,3960^{* * *} \\
(0,000)\end{array}$ & $\begin{array}{l}-0,5263 * * * \\
(0,000)\end{array}$ & $\begin{array}{l}-0,3882 * * * \\
(0,000)\end{array}$ \\
\hline $\mathrm{N}$ & 733 & 733 & 733 & 733 & 733 & 733 \\
\hline R2 & 0,3749 & 0,3077 & 0,4868 & 0,0257 & 0,0307 & 0,2972 \\
\hline Prob $>$ F-stat & 0,000 & 0,000 & 0,000 & 0,000 & 0,000 & 0,000 \\
\hline Wald Test & 0,9998 & 0,9045 & 0,9999 & 0,9438 & 0,9412 & 0,9143 \\
\hline \multicolumn{7}{|c|}{ SMALL FIRM } \\
\hline & \multicolumn{3}{|c|}{ Foreign Owners } & \multicolumn{3}{|c|}{ Foreign Ownership } \\
\hline & Total (3g) & IFRS (3h) & NonIFRS (3i) & Total (3j) & IFRS (3k) & $\begin{array}{c}\text { NonIFRS } \\
(3 \mathrm{l})\end{array}$ \\
\hline GNRL_TREND & $\begin{array}{l}-0,0365 * \\
(0,072)\end{array}$ & $\begin{array}{l}-0,0605^{* *} \\
(0,024)\end{array}$ & $\begin{array}{l}-0,0008 \\
(0,974)\end{array}$ & $\begin{array}{l}-0,0235 \\
(0,334)\end{array}$ & $\begin{array}{l}-0,0646^{* *} \\
(0,035)\end{array}$ & $\begin{array}{l}0,0272 \\
(0,150)\end{array}$ \\
\hline IFRS_TREND & $\begin{array}{l}0,0598^{*} \\
(0,052)\end{array}$ & $\begin{array}{l}0,1072^{* * *} \\
(0,014)\end{array}$ & $\begin{array}{l}-0,0270 \\
(0,556)\end{array}$ & $\begin{array}{l}0,0633^{*} \\
(0,077)\end{array}$ & $\begin{array}{l}0,1316^{* * *} \\
(0,009)\end{array}$ & $\begin{array}{l}-0,0568 \\
(0,247)\end{array}$ \\
\hline $\mathrm{C}$ & $\begin{array}{l}-2,4989 * * * \\
(0,000)\end{array}$ & $\begin{array}{l}-1,9039 * * * \\
(0,000)\end{array}$ & $\begin{array}{l}-4,1624 * * * \\
(0,000)\end{array}$ & $\begin{array}{l}-2,1226 * * * \\
(0,000)\end{array}$ & $\begin{array}{l}-1,7932 * * * \\
(0,000)\end{array}$ & $\begin{array}{l}-3,4533^{* * *} \\
(0,000)\end{array}$ \\
\hline $\mathrm{N}$ & 730 & 730 & 730 & 730 & 730 & 730 \\
\hline R2 & 0,2261 & 0,0461 & 0,3077 & 0,0389 & 0,0390 & 0,1200 \\
\hline Prob $>$ F-stat & 0,000 & 0,000 & 0,000 & 0,000 & 0,000 & 0,000 \\
\hline Wald Test & 0,0409 & 0.01103 & 0,6988 & 0,0966 & 0,0093 & 0,8755 \\
\hline
\end{tabular}

\section{REFERENCES}

[1] C. Armstrong, M. Barth, A. Jagolinzer, and E. Riedl, E. Market reaction to the adoption of IFRS in Europe, Accounting Review, 85 (2010) 31-61.

[2] J.-K. Kang and R. Stulz. Why is there a home bias? an analysis of foreign portfolio equity ownership in Japan, Journal of Financial Economics, 46 (1997) 3-28.

[3] M. Bradshaw, B. Bushee, and G. Miller, G. Accounting choice, home bias, and U.S. investment in non-U.S. firms, Journal of Accounting Research, 42 (2004) 795-841.

[4] G. Yu. Accounting standards and international portfolio holdings: analysis of cross-border holdings following mandatory adoption of IFRS, Ph.D. dissertation, The University of Michigan, (2010).

[5] M. DeFond, X. Hu, M. Hung, and S. Li. The impact of mandatory IFRS adoption on foreign mutual fund ownership: the role of comparability, Journal of Accounting and Economics, 51 (2011) 240-258.

[6] A. Florou and F. P. Pope. Mandatory IFRS adoption and investor asset allocation decisions, Working Paper, (2009).

[7] Dewan Standar Akuntansi. Proposal Konvergensi IFRS. Ikatan Akuntan Indonesia, Jakarta (2008).

[8] S. Eichler. Equity home bias and corporate disclosure, Journal of International Money and Finance, 31 (2012) $1008-1032$.

[9] M. Hamberg, T. Mavruk, and S. Sjogren. Investment allocation decision, home bias and the mandatory IFRS adoption, Journal of International Money and Finance, 36 (2013) 107-130.

[10] S. Li, S. Does mandatory adoption of International Financial Reporting Standards in the European Union reduce the cost of equity, Accounting Review, 85 (2010) 607-636. 